\title{
Information and Education Environment of Cabinet of Russian Language and Literature
}

\author{
Zhanna N.Kritarova, ${ }^{1, *}$ \\ ${ }^{1}$ ISED RAE, Centre of Philological Education, 105062, Moscow, Russia
}

\begin{abstract}
We talk about introduction of the concept of "information and education environment"(IEE) in education space and its relation to the study of Russian language and Literature in the article. Subject IEE, along with a range of equipment and information resources, must include a system of modern pedagogical technologies providing training in this field. The need for rethinking the role of a teacher in the education process is described in the article due to the fact that the methodological science is behind quickly evolving information and education environment. IEE of teaching Russian language and Literature includes elements such as purpose, content, methods, techniques, forms and training tools. However, their meanings have been changed in multimedia information and education environment. New approaches in the organization of student learning and achievement of planned results at lessons of Russian language and Literature in terms of IEE were revealed in the article.
\end{abstract}

More than twenty years, development of education in our country is connected with the word "standard", which first appeared in the Law of Russian Federation"On education" in 1992. On the basis of the Federal component of the state education standards of the first generation (order of the Ministry of education of Russian Federation No. 1089 on 05.03.2004) prepared the letter from the Ministry of Education and Science of the Russian Federation from 01.04. 2005 No. 03-417 "About the list of training and computer equipment for the educational institutions," [1]. On the basis of methodological recommendations education organizations formed material and information environment of the education process.

The most important stage of modernization of general education was approval and introduction of the new Federal state educational standards (FSES). The standards of basic general education (17 December, 2010 No. 1897) introduced the concept of "information and education environment", which includes "a complex of information and education resources, including digital education resources, set of technological means of information and communication technologies(ICT): computers, other ICT equipment, communication channels, the system of modern pedagogical technologies," [2]. The complex of resources, listed in this definition, in this or that way accompanied by the learning process before.

A special interest was emerged to the concept of "education environment" as a complex of factors determining the learning and development of personality in the '90th years of the twentieth century. However, there is no unified understanding of its content in science on this day.

A new round in development of information technologies, need to have a good understanding them, and the requirements of the FSES for the results of mastering program material and the conditions of implementation of education process involve creation of a modern education environment and education organizations, and subject-specific classrooms.

In addition, in the standards we are talking about extracurricular activities of students carried out during the second half of a day in school classrooms. In this regard, implementation of the requirements of the FSES to resourcing of the information-subject environment of the Cabinet, as a component of information education environment of education establishment, is crucial.

And "in the definition of the notion "information subject environment" the meaning of the term "subject" is changing in the given context :"subject" is not a separate school subject, but a system of interconnected and interrelated general components of different academic disciplines, different fields of knowledge [3, p.377].

New information-subject environment may be the basis for the integration of multiple subject areas, to activate "items-intermediaries" which, according to the words of E.V.Il'enkov, are "structurally constitutive component of cognition" [4, p.183-210]. Thus, the subject of information and education environment is the integrative result of interaction of its components and aimed at optimization of an education process.

Education and material base of teaching Russian language and Literature traditionally serves as

\footnotetext{
Corresponding author:kg1978@yandex.ru
} 
classrooms, which hosts academic and extra-curricular classes, is education equipment and implemented an active education and cognitive activity of students.

Today, information and education environment of a Cabinet of Russian language and Literature should include a range of equipment and information resources that meet the requirements of the XXI century.

\section{The complex of technical means of training:} -workstations; -specialized software and hardware complex of the teacher (monoblock with preinstalled software); -loudspeakers; interactive whiteboard and other classroom boards; -multimedia projector; -multifunction printer (MFP); -overhead projector; -document camera; -interactive testing system;

- digital camera;

- digital video camera;

-Wi-Fi router;

- auditorium sound system;

-the automated workplace of the learner.

The complex of training materials. Complex visual-demonstration of printed learning tools.

Complex e-learning tools:

-electronic application for textbooks of Russian language and Literature;

-e-posters, tables, dictionaries, reference books; -interactive posters;

-media guides;

-electronic audiophobe in literature; -educational videos;

-feature films.

\section{Complex resources on the Internet (cloud resources):} -Internet resources;

-education sites;

-virtual dictionaries;

-literary sites and museums;

-projects of the year of Literature;

-social network community.

One of the main principles of formation of information and education environment of Russian language and Literature is the principle of presentation, because according to experts, about $80-90 \%$ of the information on world around a person receives with the help of view. The education principles relate to learning methods. There are different classifications of teaching methods. Classification of teaching methods according to sources of knowledge is the earliest in didactics at the time of creation. As sources of knowledge a word, a vision, physical activity of the personality are considered, and verbal, visual and practical teaching methods are respectively allocated. Verbal teaching methods include narration, explanation, lecture, conversation, discussion. Illustrations, demonstrations are referred to visual methods. Practical ones include exercises, laboratory and practical works, work with a book [5, p.10]. The use of visual teaching methods activates cognitive activity of the students, makes the learning process fast and durable. Visual learning techniques are implemented through training.

Means of presentation used at the lessons of Russian language and literature, can be permanent or temporary. This division is conditional, since the decision always remains with a teacher.

Stands (information, profile, congratulatory, stands quotes, etc.), portraits of writers belong to visual aids of continuous presentation

Vinyl tables, kodotransparant, posters belong to visual aids of temporary presentation.

One of the key components that is part of IEE education electronic publications of various types. The electronic edition represents the combination of text, graphics, speech, music, video, photos and other information, and printed user documentation. The electronic manual can be performed on any electronic media, or placed in a local or global computer network. Depending on the content, scope and completeness of training material e-learning publications should be divided into electronic textbooks, electronic training manual, electronic problem books, e-workshops, etc. Emergence of multimedia - "multi environments"- is connected with creation of electronic manuals- areas of the computer technology based on simultaneous use of several data representation forms (graphics, the text, animation, sound, and video). Among the multimedia tools in education process a special role belongs to multimedia tutorials. Multimedia tutorials are computer training programs designed for organization of the learning process on students' computer. Modern multimedia manuals are often interactive, what gives them a significant advantage in comparison with other means of presenting information. Interactive visual manual usually includes:

- objects of visual information, practical training,

- test control of students' knowledge system,

- $\quad$ additional information.

Development of interactive multimedia manuals is associated with emergence of interactive whiteboards that require special manuals. Information and education environment of Russian language and literature involves not only a complex of information education resources, set of technological means of ICT (computers etc.) but the system of modern pedagogical technologies providing training in this environment.

Today it is impossible to prepare for classes with the thought "how to use a presentation in class?", that is, the traditional lesson on the basis of modern means of education. There is a need to look at the problem: "what technology should be used to the subject and the definite lesson was interesting to students?" A difficult task, methodology as a field of science is behind the fast emerging information and education environment. We need to rethink the role of a teacher in the education process. Before the teacher was the only source of 
knowledge, today on the Internet you can find any information. The teacher in the modern school should act rather as a guide, a kind of a guide in search for the necessary knowledge. Everything is back to normal. Historically there was a saying: give a man a fish and you feed him for a day, teach a man to fish and you feed him for a lifetime.

Modern pedagogical technologies providing training in IEE are specially worked out to help a teacher and his students in the educational process. Scientists have proved that the nature of training affects development of mental structures of a person, including thinking. Printed text is organized as a linear sequence of phrases in the reading process that generates a similar structure of mental activity. In information and education environment in a linear organization of a text wedged footnotes, comments, images, videos and audio snippets, which violates linearity, creates models of recognition, addressed to the emotional side of the subject and change the mindset becomes nonlinear, and more fluid, flexible, inclined to creative manifestations [6]. Therefore, when learning through information and communication technologies methods of linear (traditional) and nonlinear (hypertext) thinking must be integrated. A key figure in the IEE remains the Teacher, who must fully possess ICT competence, designed to support the implementation of new educational goals, new forms of organization of educational process, a new content of educational activity.

Like any education system, information and education environment of philological education includes elements such as purpose, content, methods, techniques, forms and training tools. But multimedia information and educational environment fundamentally changes their meaning.

Learning objectives, for example, in literature in information and education environment is development of the competencies required for an individual and a society and associated with planned learning outcomes through use of computer and ICT, namely: - development of intellectual and creative abilities for successful socialization and self-realization; - formation of skills of reading, commenting a text; mastering algorithms of realization of meanings in literature, essential General education skills and universal education actions; - use of the experience of interaction with a book in everyday life and education activity, speech improvement.

In the process of implementing these objectives, a teacher becomes a facilitator in the learning process and a learner is its active subject, aiming to develop general and subject competences.

A lesson in IEE isn't structurally very different from traditional: actualization of knowledge, explanation of new material, consolidation, control are also relevant today. However, this structure is filled with different content based on the following factors: a ratio of information assembled to a particular lesson, and information on the Internet; a focus on prompt feedback to students; the ability to use a variety of forms of organization of learning activities, including individual educational trajectory; great opportunities for organization of project activities of students. When using traditional teaching methods individual, group, collective forms of organization of education activity become topical. Work on joint education projects based on ICT develops communicative and information competences. Thus, a computer becomes a universal learning tool: it not only replaces all of the traditional demonstration of the device, but is a source of information, performs the function of a teacher, work tool, working team, game environment, visual aids with effects of media and telecommunications, simulator, text editor, means of diagnostics and control [7, p.34].

Conducting lessons in Russian language and Literature in information and education environment allows to successfully develop intellectual potential and to develop creative abilities of pupils, to develop computer technology and to vary the work with them. It is important when using EER on the lesson a teacher has ability to control a rate of flow of a material, to focus attention on key regulations topics, to reiterate and explain the provisions which caused difficulty in students' work, to manage work of students in a notebook.

The school course of Russian language is usually divided into several main areas, where use of ICTs is justified, namely:

-acquaintance with linguistic phenomena;

-spelling and punctuation studies;

-work with text;

-work on development of speech's culture;

-system of test control;

-preparation for state exams.

When introducing a lesson with a new linguistic phenomenon, it's quite necessary to appeal to visualdemonstration means of learning. It may be spreadsheets, slides and other types of local EER, among which multimedia presentation is at special place. The presentation (lat. praesento - submission) is a bright sign of a modern lesson. A presentation may be a combination of text, hypertext links, computer animation, graphics, video, music and audio series, which is organized into a single environment. A presentation has a plot, script and structure, organized for convenient information perception. A distinctive feature of a presentation is its interactivity. It can be performed for demonstration or training purposes. It is a presentation that helps in a better visualization of a subject, as it is possible to move illustrations on a screen to match them with a plot, highlighting, bold important words, use of animated effects, such as flicker, identifying semantic elements of a text. When preparing a presentation, remember a few rules:

- a content of a presentation should be clearly structured; - quantity of slides should be optimally 20-25 slides; - amount of text in presentations should not exceed 35$40 \%$.

There are several programmes to prepare presentations. In school training Microsoft PowerPoint (full name Microsoft Office PowerPoint, from English “ power point" - persuasive report)is widely used programme in a training presentation that is part of 
Microsoft Office and available in editions for Microsoft Windows operating systems and Mac OS. Materials prepared with the help of PowerPoint, are designed for display on a large screen through a projector or television screen of large size [8]. Recently in school to create an interactive presentation with nonlinear structure the programme Prezi is used. Unlike "classic" presentations made in Microsoft PowerPoint where presentation is divided into slides, Prezi main effects are not related to transition from slide to slide, and with increase in separate parts of the same slide. You can learn more about this program and sign up for free in a master class on creating it on the site [9].

The presentation, as a mean of visualization, allows to present a teaching material as a system of reference images of bright, filled with comprehensive structured information. A presentation is especially relevant at generalization-lessons on a theme under study. A teacher knows possibilities of students sitting in front of him, their psychological and emotional features. So generalization-lessonmust be organized in accordance with these features. And here a presentation prepared by a teacher can help. A presentation should not only present a subject in a single system of holistic perception, combining diagrams, tables, conclusions, examples, etc., but also give an appropriate emotional state. A theme of a lesson will be deeply perceived, if in preparing a presentation, students are involved. One should be asked to prepare a slide with a table, anotherconclusions, etc. to perform this seemingly small work, a student should review an education material on a whole topic, look for additional material to consider how all read to put in one slide. A teacher connects slides prepared by students like a quilt in one presentation. Of course, everything should be checked, edited if necessary and formed in one and the same style. In this case, a teacher can be sure that a new topic is learned by everybody in a class.

When working with a text at lessons of Russian different forms and techniques can be used: e.g., reconstruction of acultural background of individual words and expressions; etymological comments on texts; a comparison of Russian words with words and equivalents in other languages; use of all types of complex text analysis; work with concepts - names of the most important subjects or concepts in a mental world of a person (carnival, Kaftan, Gzhel', mercy, etc.)

A presentation can be used actively at Literature lessons. During lectures, exploring a new material, a presentation can serve as a main form of a lesson (when it is loaded with a significant part of information) and a secondary (in this case it is used as a visual aid or reference notes).For example, at a lesson of Literature in the 5th grade in the presentation "I. S. Turgenev. Mumu" one of slides can tell that Director Yuri Grymov and sculptor Vladimir Tsessler from Minsk in 1998 on the shores of the English channel in the French city of Honfleur, founded a sculpture of $\mathrm{Mu}-\mathrm{Mu}$ as a symbol of love and loneliness. Another slide may represent a composition of a literary masterpiece: clotted tangle of cast-iron dog, slumbering peacefully on a step at the entrance to the club-cafe "Mumu", and a plaque that says
"150 years ago in the journal "Sovremennik" the short story "Mumu" was published. The monument was erected for the 150th anniversary of the publication of the famous work on the $25^{\text {th }}$ of March, 2004 in St. Petersburg.

When a projector displays color portraits of writers, illustrations to works, photos, it quickens the course of a lesson, awakening students' interest to literary works, allowing you vividly imagine a life and personality of a writer. This form of work allows you to work directly with a whole class.

A lesson of text analysis allows you to implement an integrative approach to learning. Interpreting a text, a student should see a variety of interpretations of concepts and definitions, which allows making a presentation. Problem and research training is becoming leading in these lessons. A composition of the presentation should reflect uniqueness of a composition of a text. On slides one can find not only additional material but tasks, processed intermediate and final conclusions are also formulated. Seminar-lesson or generalization-lesson with use of a presentation has special logic in a construction and effectiveness in teaching. In working with presentations individual approach to learning is realized, a process of socialization and self-identity is activated, historical, scientific and natural thinking is developed. A presentation may be a form of reporting on completion of a literary project. Among the projects it may be development of a multimedia collection of literary works (search and selection of texts, title, introduction, illustrations, sound recordings); album devoted to a work or a writer; a subject of newspaper, magazine, booklet; reports; tours of literary places; a school play or a poetic composition with use of creative works by students (drawings, photographs, sound recordings). Projects can be very diverse, as long as they are interesting to students, original and significant. Unfortunately, the Internet is filled with projects which have been spread on traditional themes, and a certain part of students is fed to temptation to use a finished product as a result. Organization of project activities requires serious preparation, attention, and thoughtfulness. In the course of a project students learn to independently acquire knowledge, gain experience and learning and teaching activities. If a student receives in school research skills of orientation in a flow of information, learn to analyze, to generalize, to see a trend, compare facts, make findings and conclusions, it is due to a higher education level will be easier to adapt later in life. Project activity at a lessons of Literature contributes to a greater extent than other disciplines to formation of personal results, promote improvement of moral qualities of students.

Working with ICT in lessons of Russian language and Literature is of great interest to students, stimulates their cognitive activity and creative abilities. However, it should be remembered that:

- it is important to use ICT at lessons, not only as illustrative material and, primarily, as a basis for structuring and organizing information, creative application of acquired knowledge; 
- there is a need to plan work on synthesis and consolidation of educational material of courses of Russian language and Literature through use of multimedia encyclopedias, inclusion of test tasks and knowledge, abilities and skills on training simulators in training programs;

- work with projects to plan group projects and to aim students at independent activities;

- you need to keep in mind the age and physiological features of students when using ICT at lessons of Russian language and Literature.

Information and education environment of a Cabinet opens up great opportunities in teaching students and achievement of planned results at lessons of Russian language and Literature.

\section{References}

1. Ofitsialnye dokumenty. Available online: URL http://docs.cntd.EN/document/901932045 (accessed on 09.10.15) [In Rus]
2. Ofitsialnye dokumenty. Available online: URL http://www.rg.EN/2010/12/19/obrstandart-site dok.html (accessed on 09.10.15) [In Rus]

3. Instrumental'naya didaktika: perspektivnye sredstva, sredy i tekhnologii obucheniya, (Nestor-Istoriya, Sankt-Peterburg,1979) [In Rus]

4. E.V.Il'enkov Dialekticheskaya logika (Nauka, Moskva, 1979). [In Rus]

5. I.M. Osmolovskaya, Naglyadnye metody obucheniya (Akademiya, Moskva, 2009) [In Rus]

6. Mul'timedia v obrazovanii. Available online: URL // http://www.ido.rudn.ru/Open/multimedia [In Rus]

7. 7. N.V. Belyaeva, Modernizatsiya shkol'nogo literaturnogo obrazovaniya $v$ kontekste informatsionno-obrazovatel'noi sredy (Econ-inform, Moskva, 2012) [In Rus]

8. PowerPoint. Available online: URL //https://EN.wikipedia.org/wiki/Microsoft_PowerPoi nt (accessed on 19.12.15) [In Rus]

9. Prezi. Available online: URL //http://prezinarusskom.E/index/obuchenie_po_prezi /0-15(accessed on 14.01.16) [In Rus] 